\title{
Lactic acid bacteria isolated from dairy products as potential producers of lipolytic, proteolytic and antibacterial proteins
}

\author{
Israel García-Cano ${ }^{1}$. Diana Rocha-Mendoza ${ }^{1}$. Joana Ortega-Anaya ${ }^{1} \cdot$ Karen Wang $^{1} \cdot$ Erica Kosmerl $^{1}$ • \\ Rafael Jiménez-Flores ${ }^{1}$ (D)
}

Received: 16 January 2019 / Revised: 8 April 2019 / Accepted: 10 April 2019 / Published online: 27 April 2019

(C) The Author(s) 2019

\begin{abstract}
Regular consumption of fermented dairy products helps maintain a healthy microbiota and prevent gut dysbiosis-linked diseases. The lactic acid bacteria (LAB) present in food enhance the digestibility of proteins, moderate the release of fatty acids, and support human health through inhabiting the gastrointestinal tract. These desirable properties of LAB are attributed, in part, to their metabolic processes involving enzymes such as lipases, proteases, and antibacterial proteins. The LAB strains presenting higher enzymatic activities may offer improved functionality for applications in foods. The first aim of this work was to isolate and identify LAB from diverse dairy products and select those with enhanced enzymatic activities. Secondly, this work aimed to investigate the subcellular organization and identity of these enzymes after semi-purification. Out of the total 137 LAB strains isolated and screened, 50.3\% and $61.3 \%$ of the strains exhibited lipolytic and proteolytic activities, respectively. Seven strains displaying high enzymatic activities were selected and further characterized for the cellular organization of their lipases, proteases, and antibacterial proteins. The lipolytic and proteolytic activities were exhibited predominantly in the extracellular fraction; whereas, the antibacterial activities were found in various cellular fractions and were capable of inhibiting common undesirable microorganisms in foods. In total, two lipases, seven proteases, and three antibacterial proteins were identified by LC-MS/MS. Characterization of LAB strains with high enzymatic activity has potential biotechnological significance in fermentative processes and in human health as they may improve the physicochemical characteristics of foods and displace strains with weaker enzymatic activities in the human gut microbiota.
\end{abstract}

Keywords Lactic acid bacteria $\cdot$ Dairy products $\cdot$ Zymography $\cdot$ Bioactivity

\section{Introduction}

Lactic acid bacteria (LAB) encompass a wide group of microorganisms belonging to the genera Enterococcus, Lactobacillus, Lactococcus, Leuconostoc, Pediococcus, and Streptococcus, among others (Burgain et al. 2014). $\mathrm{LAB}$, found naturally in some foods, participate in food fermentation processes and are intentionally added as starter cultures to improve color development, reduce ripening periods, and enhance sensory characteristics including flavor, aroma, and texture. Additionally, LAB fermentation

Rafael Jiménez-Flores

jimenez-flores.1@osu.edu

1 Department of Food Science and Technology, Parker Food Science and Technology Building, The Ohio State University, Columbus, OH 43210, USA improves food digestibility and increases product safety through inhibition of spoilage and pathogenic bacteria (Papagianni 2012). Beyond these important physicochemical roles, some LAB strains are considered to be probiotics due to their beneficial effect on the intestinal tract and human health (Jankovic et al. 2010). These meaningful implications make understanding the functionality of LAB an industrially and nutritionally relevant topic.

The biochemistry of fermented products is complex, involving a series of many enzymatic reactions. Among the changes that occur during food fermentation are a decrease in $\mathrm{pH}$ and the inhibition of other microorganisms due to the production of metabolites such as lactic acid, hydrogen peroxide, diacetyl, acetaldehyde, reuterin, and peptides (Papagianni 2012). Additionally, fermentation leads to the production of antibacterial compounds and other molecules derived from metabolism such as lipolytic and proteolytic enzymes (Burgain et al. 2014). 
Lipolysis is the hydrolysis of triglycerides to produce free fatty acids, glycerol, and intermediates such as mono- and diglycerides. These intermediates emulsify other food components, which aid in texture development of the final product (Esteban-Torres et al. 2014). The degree of lipolysis by LAB helps determine the selection of the strains used as starter cultures. This property is extremely relevant for vegetable fermentation, baked food applications, and flavor development in fermented milk products (Tanasupawat et al. 2015).

LAB are generally considered to be weakly lipolytic relative to species of the Penicillium and Pseudomonas genera (McSweeney and Sousa 2000). However, in products such as cheeses with extended ripening periods, lipolytic activity from $\mathrm{LAB}$ contribute to flavor development and serve as substrates for further reactions producing catabolic end products (Collins et al. 2003).

$\mathrm{LAB}$ are not distinguished for their lipolysis, but some reports of lipolytic activity have been made in Lactobacilli strains. Specifically, the lipolytic activity of $L$. helveticus, L. delbrueckii, L. bulgaricus. L. casei, L. plantarum, and L. acidophilus species have been studied (El-Soda et al. 1986; Fernandez et al. 2000).

Proteolysis is the hydrolysis of peptide bonds in proteins to generate peptides and free amino acids. Free amino acid formation and subsequent participation in decarboxylation, deamination, transamination, and desulfurization reactions play a crucial role in determining food flavor. Proteases are pertinent to the development of fermented products because they are associated with the release of these molecules directly responsible for desirable aroma, texture modification, and reduced $\mathrm{a}_{\mathrm{w}}$ of some products such as aged cheeses (Savijoki et al. 2006). In fermented dairy foods, milk protein proteolysis improves the digestibility of products, a characteristic highly desired by the infant formula industry. Proteolysis also reduces whey protein antigenicity thought to provoke an immune response in some individuals. Furthermore, the bioactive peptides obtained from milk protein proteolysis reduce microbial infections (Atanasova et al. 2014). Many LAB including Lactococcus, Lactobacillus, and Streptococcus are considered weakly proteolytic strains. Nevertheless, proteolysis is one of the major and more complex enzymatic reactions occurring in dairy products (McSweeney and Sousa 2000). $\mathrm{LAB}$ possess a very intricate proteinase/peptidase system which is comprised of three components: proteases bound to the cell wall that initiate the degradation of casein into oligopeptides, peptide transporters, and intracellular peptidases that degrade peptides into shorter peptides and free amino acids. The components of the LAB proteolytic system have been studied by genome analysis; however, the complexity of this system hinders the purification and identification of many involved proteins that remain uncovered (Liu et al. 2010).

Lastly, the proteins exerting antibacterial activity have been widely studied. Among these, bacteriocins constitute one of the most important classes of antibacterial proteins found in LAB. Bacteriocin is a generic term for peptides with antimicrobial activity. Bacteriocins are a result of adaptation that has allowed LAB to compete favorably against other phylogenetically related microorganisms for the nutrients in their habitat and participate in cellular communication (Álvarez-Sieiro et al. 2016). They have been classified and categorized by several ways: molecular weight, sequence or posttranslational modifications, source organism, lytic ability, mode of action, and substrate or target, among others. Regardless of these classifications, bacteriocins that degrade peptidoglycan in the bacterial cell wall are designated as bacterial cell wall hydrolases, autolysins, or peptidoglycan hydrolases (PGHs) (Callewaert et al. 2011). These enzymes exert their antibacterial activity by hydrolysis of the glycosidic or peptide bonds of peptidoglycan, the major component of the bacterial cell walls. Bacteriocins in general and specifically PGHs from LAB show potential for application in GRAS biopreservation of fermented food since they have potent activity in vivo and in vitro especially against pathogenic Grampositive bacteria. Moreover, these proteins have activity against antibiotic-resistant bacteria because of their unique mechanism of action, completely different from that of antibiotics (Callewaert et al. 2011; Rodríguez-Rubio et al. 2016). Because of the wide variety of enzymes with antimicrobial activity produced by LAB, the discovery and characterization of new or putative proteins constitutes a niche of research that is imperative to explore.

As mentioned, LAB constitute an important source of enzymes that help shape desired sensory characteristics in dairy products and impart benefits on the gastrointestinal tract when ingested in the diet. The aim of this work was to investigate the enzymatic activities of $\mathrm{LAB}$ isolated from dairy products and determine their subcellular organization and identity after semi-purification. This study is of significance as it provides insight into LAB metabolism of food-derived components and has a potential impact in modification of the microbiome upon ingestion, as shown in many in vitro and in vivo studies (Derrien and van Hylckama Vlieg 2015).

\section{Materials and methods}

\section{Bacterial isolation}

Dairy products including raw milk, milk powder, buttermilk powder, yogurt, cheese, and cream were purchased from local food stores (Columbus, OH, USA). Twenty-five grams of each sample was homogenized in $250 \mathrm{ml}$ of sterile saline solution $(0.85 \% \mathrm{NaCl}, \mathrm{pH} 7.0)$ using a Stomacher 80 Biomaster for $1 \mathrm{~min}$ at $300 \mathrm{rpm}$ (High speed, Seward, UK). Afterwards, serial dilutions of $10 \mathrm{ml}$ were prepared from each sample and plated on MRS agar (Difco, USA) with 
bromocresol green $(0.0025 \%)$ as a $\mathrm{pH}$ indicator. The plates were incubated for $24-48 \mathrm{~h}$ at $37^{\circ} \mathrm{C}$ under anaerobic conditions. Colonies were selected based on phenotypic features such circular shape, creamy texture, white, gray, or green color and were further regrown in MRS broth and agar until complete isolation.

\section{Screening of lipolytic and proteolytic activity}

Lipolytic activity screening was performed following the protocol described by Peña-Montes et al. (2013) using $p$-nitrophenyl acetate as substrate ( $p$-NPA; Sigma-Aldrich, USA). Fifty microliter of each isolated strain culture were mixed with $50 \mu \mathrm{l}$ of substrate and incubated at $37{ }^{\circ} \mathrm{C}$ for $1 \mathrm{~min}$ intervals over a $1 \mathrm{~h}$. The absorbance of the colored complex was measured at $410 \mathrm{~nm}$ in a spectrophotometer (Multiskan Go, Thermo Fisher, USA). Lipase from porcine pancreas (Sigma-Aldrich) was used as positive control. One unit was defined as the quantity of enzyme that releases $1 \mu \mathrm{mol}$ of $p$ nitrophenol per min at $37^{\circ} \mathrm{C}$. The proteolytic activity was determined by quantification of colorimetric azo groups released from a synthetic azocasein (Sigma-Aldrich), as Bendicho et al. (2002) described. Fifty microliter of each strain culture were mixed with $500 \mu \mathrm{l}$ of azocasein $(0.5 \mathrm{mg} / \mathrm{ml}$ in Tris- $\mathrm{HCl}, \mathrm{pH}$ 7.6) and incubated at $37{ }^{\circ} \mathrm{C}$ for $2 \mathrm{~h}$. The reaction was stopped with $500 \mu \mathrm{l}$ of $10 \%$ TCA (Fisher Chemical, USA). The suspension was centrifuged at $13,000 \times \mathrm{g}$ for $10 \mathrm{~min}$. One-part supernatant was mixed with one-part $50 \% \mathrm{NaOH}$. $\alpha$-chymotrypsin from bovine pancreas (Sigma-Aldrich) was used as a positive control. The absorbance of azo groups was measured at $440 \mathrm{~nm}$ and the final proteolytic activity was defined as the amount of the enzyme yielding $\Delta \mathrm{Abs}_{440 \mathrm{~nm}}=0.01$ per min.

Lactococcus lactis strain purchased from $\mathrm{Chr}$. Hansen (Hoersholm, Denmark) was used as a positive control. The strain was inoculated in MRS broth and incubated at $37{ }^{\circ} \mathrm{C}$ for $12 \mathrm{~h}$, and then the culture was used for lipolytic and proteolytic activities.

\section{Antibacterial activity}

To analyze the antibacterial activity towards different substrates, four techniques were employed: (a) $\mathrm{N}$-acetylglucosaminidase activity was measured using the substrate 4-nitrophenyl Nacetyl- $\beta$-D-glucosamine (NP-GlcNAc; Sigma-Aldrich; GarcíaCano et al. 2015). Ten microliter of $1 \mathrm{mg} / \mathrm{ml}$ NP-GlcNAc solution was placed in a 96-well plate along with $10 \mu \mathrm{l}$ of sample and $80 \mu \mathrm{l}$ of sodium citrate buffer ( $100 \mathrm{mM}, \mathrm{pH} 4.8)$. Ten microgram per milliliter of the $\beta$-nacetylglucosaminidase from Canavalia ensiformis (Sigma-Aldrich) was used as a positive control. The reaction mixture was incubated at $37^{\circ} \mathrm{C}$ for $10 \mathrm{~min}$ and $100 \mu \mathrm{l}$ of sodium carbonate $(140 \mathrm{mM})$ was used to stop the reaction and enhance the color. Absorbance at $405 \mathrm{~nm}$ was determined. One unit was defined as the amount of enzyme that hydrolyzes $1.0 \mu \mathrm{mol}$ of 4-nitrophenyl $\mathrm{N}$-acetyl- $\beta$-D-glucosamine to 4nitrophenol and $\mathrm{N}$-acetyl- $\beta$-D-glucosamine per minute at $\mathrm{pH} 4.7$ at $37^{\circ} \mathrm{C}$. (b) N-acetylmuramoyl-L-alanine amidase activity was performed using the substrate L-alanine- $p$-nitroanilide hydrochloride (Sigma-Aldrich; García-Cano et al. 2015). Ten microliter of $1 \mathrm{mg} / \mathrm{ml}$ substrate solution was placed in a 96well plate along with $10 \mu \mathrm{l}$ of the assayed sample and $80 \mu \mathrm{l}$ Tris-HCl buffer (100 mM, pH 7.6). The reaction mixture was incubated at $37{ }^{\circ} \mathrm{C}$ for $10 \mathrm{~min}$. Absorbance at $405 \mathrm{~nm}$ was determined. One unit was defined as the amount of enzyme that will hydrolyze $1.0 \mu \mathrm{mol}$ of L-alanine- $p$-nitroanilide to $p$ nitroaniline per minute at $\mathrm{pH} 7.6$ at $37^{\circ} \mathrm{C}$. An amidase from Pseudomonas aeruginosa (Sigma-Aldrich) was used as a positive control. (c) The turbidimetric assay for $\mathrm{N}$-acetylmuramidase activity was measured using whole Micrococcus lysodeikticus cells (Sigma-Aldrich; Morsky 1983). The cells were resuspended in Tris-HCl pH 7.6 until an optical density (O.D.450nm) of 1.0 was obtained. Two hundred microliter of each suspension was preincubated at $37{ }^{\circ} \mathrm{C}$ for $10 \mathrm{~min}$. The reaction was initiated by the addition of $50 \mu \mathrm{l}$ of the sample. The reaction mixture was measured at $37{ }^{\circ} \mathrm{C}$ for $1 \mathrm{~min}$ intervals over a $1 \mathrm{~h}$. One unit of lytic activity was defined as the amount of enzyme resulting in a decrease in the $\Delta$ O.D. $450 \mathrm{~nm}$ of 0.001 per min. Lysozyme from chicken egg white (Sigma-Aldrich) was used as a positive control. (d) Endopeptidase activity was performed using peptidoglycan from Staphylococcus aureus as the substrate in the turbidimetric assay (Sigma-Aldrich; Zhou et al. 1988). Peptidoglycan was resuspended in Tris-HCl pH 7.6 until O.D. $620 \mathrm{~nm}$ reached 0.5. Two hundred microliter of each suspension was preincubated at $37^{\circ} \mathrm{C}$ for $10 \mathrm{~min}$. The reaction was initiated by the addition of $50 \mu \mathrm{l}$ of the sample. The reaction mixture was measured at $37^{\circ} \mathrm{C}$ for 2 min intervals over a $2 \mathrm{~h}$. One unit of lytic activity was defined as the amount of enzyme resulting in a decrease in the $\Delta$ O.D. ${ }_{620 \mathrm{~nm}}$ of 0.001 per min. Lysostaphin from Staphylococcus staphylolyticus (Sigma-Aldrich) was used as a positive control. To complement these experiments, agar diffusion assays were performed as described by García-Cano et al. (2014) using the following strains as targets: Escherichia coli ATCC 25922, Listeria innocua ATCC 51742, Staphylococcus aureus ATCC 25923, and Staphylococcus epidermidis ATCC 1222. All strains were grown in BHI broth (Difco, USA) at $37{ }^{\circ} \mathrm{C}$ for $12-14 \mathrm{~h}$ without stirring.

\section{Identification of bacterial strains by $16 \mathrm{~S}$ rRNA sequencing}

Genomic DNA (gDNA) was extracted from freshly prepared cultures grown in MRS broth. The cells were first pelleted by centrifugation at $10,000 \times g$ for $10 \mathrm{~min}$ at $4{ }^{\circ} \mathrm{C}$ (Centrifuge 5415R, Eppendorf, USA) and washed two times using one volume of sterile saline solution. The gDNA of each LAB was isolated using Wizard Genomic DNA Purification Kit 
(Promega, USA) following the manufacturer's protocol. To amplify the complete 16S rRNA gene, identical conditions and primers reported by García-Cano et al. (2014) were used in conjunction with a Platinum Taq DNA Polymerase (Thermo Scientific, USA) in a Thermal Cycler Eco (Eppendorf, Germany). The resulting amplicons were purified using a Wizard ${ }^{\circledR}$ SV Gel and PCR Clean-Up system (Promega, USA), and the sequencing experiments were performed by Macrogen Inc. (Seoul, South Korea). The sequences obtained were aligned with the 16S rRNA reference gene sequence from GenBank using the Basic Local Alignment Search Tool (BLAST) algorithm available from the National Center of Biotechnology Information (date of query: May 2018).

\section{Accession number}

The 16S rRNA sequences have been deposited at GenBank under the accession number: $P$. acidilactici OSU-PECh-L, MK543955; L. casei OSU-PECh-C, MK543956; L. plantarum OSU-PECh-A, MK543957; P. acidilactici OSU-PECh-3A, MK543958; L. paracasei OSU-PECh-3B, MK543959; L. paracasei OSU-PECh-BA, MK543960; and L. plantarum OSU-PECh-BA, MK543961.

\section{Preparation of cellular fractions}

In order to identify the cellular location of the aforementioned enzymes, four cell fractions were prepared and evaluated, as follows: (a) cell-free extract (supernatant), (b) intracellular fraction, (c) cell-debris fraction, and (d) whole cell fraction. After overnight incubation at $37^{\circ} \mathrm{C}$, the whole culture media was centrifuged at $8000 \times g$ for $10 \mathrm{~min}$ at $4{ }^{\circ} \mathrm{C}$, and the supernatant fraction was removed from the bacterial cell pellet. After the $\mathrm{pH}$ was adjusted to 7.0, the supernatant fraction was filtered by a $0.22 \mu \mathrm{m}$ cutoff sterile membrane (Millipore, USA) and kept at $-20{ }^{\circ} \mathrm{C}$. The pellet, corresponding to the whole cell fraction, was washed two times with one volume of PBS and resuspended in the same buffer before adjusting the O.D. ${ }_{600 \mathrm{~nm}}$ to 2.5 in order to standardize the enzymatic activities. The intracellular and cell-debris fractions were obtained using ultrasonication to disrupt the cells by the following conditions: 20 cycles of $20 \mathrm{~s}$ sonication at $20 \mathrm{~Hz}$ followed by $20 \mathrm{~s}$ rest (Branson Sonifier 450; Fisher, USA). The intracellular fraction was recovered by centrifugation at $15,000 \times g$ for $30 \mathrm{~min}$ at $4{ }^{\circ} \mathrm{C}$, and the cell-debris fraction (pellet) was also collected. The four factions obtained were tested for enzymatic activity.

\section{Protein concentration assay}

The amount of protein in each fraction was measured following the instructions of Bradford protein assay kit (Bio-Rad, USA). Bovine serum albumin was used as a protein standard.

\section{Protein isolation by zymography}

To isolate the proteins responsible for each enzymatic activity, zymography was performed with copolymerized polyacrylamide gels testing each cell fraction obtained. Briefly, lipolytic activity was observed by $10 \%$ polyacrylamide gel electrophoresis (PAGE) using $\alpha$-naphthyl acetate as the substrate (Sigma-Aldrich), according to Peña-Montes et al. (2013). The proteolytic activity was tested with SDS-PAGE using casein as the substrate, as described by Stuknyte et al. (2016). The antibacterial activity against M. lysodeikticus was evaluated according to García-Cano et al. (2015). The molecular weight of the bands displaying lipolytic, proteolytic, or lytic activities were determined using a Precision Plus Protein ${ }^{\mathrm{TM}}$ Standard (Bio-Rad, USA) and analyzed using a ChemiDoc ${ }^{\mathrm{TM}}$ Touch imaging system (Bio-Rad, USA).

Each protein band that displayed activity in the zymograms was excised from the gel, placed in a $1.5 \mathrm{~mL}$ tube, triturated in $500 \mu \mathrm{L}$ of sterile deionized $\mathrm{H}_{2} \mathrm{O}$, and incubated overnight at room temperature. Afterwards, the solution was filtered through a $0.22 \mu \mathrm{m}$ cutoff sterile membrane to eliminate the gel material and was subsequently concentrated by ultrafiltration with an Amicon ${ }^{\circledR}$ Ultra Centrifugal Filter $(0.5 \mathrm{ml}, 10-\mathrm{kDa}$ cutoff; Millipore, USA). Finally, each isolated protein was loaded into an SDS-PAGE for further analysis by LC-MS/MS.

\section{Protein identification by LC-MS/MS}

The proteins were sent for sequencing analysis at the Campus Chemical Instrument Center (CCIC), Mass Spectrometry and Proteomics Facility at The Ohio State University (Columbus, Ohio, USA). Protein bands were subjected to in-gel trypsin digestion, and the resulting peptides analyzed by capillary LC-MS/ MS. Peptide fragments generated by tandem MS were compared with the MASCOT database to obtain the amino acid sequence. Proteins with at least two matching peptide fragments to the database were considered reliable identification hits.

\section{Results}

\section{Bacteria isolation, initial screening of lipolytic and proteolytic activities, and strain identification by 165 rRNA sequencing}

After initial selection, each strain was grown in MRS agar plates to confirm isolation. A total of 137 strains were isolated from different dairy products and given a specific designation code (OSU-PECh). The initial screening for lipolytic activity, using $p$-NPA as the substrate, showed that $50.3 \%$ of the total isolated strains exhibited lipolytic activity and, furthermore, seven strains resulted in high lipolysis compared to the positive control (L. lactis; Fig. 1a). Values above $0.15 \mathrm{U} / \mathrm{min} * \mathrm{~mL}$ 
were deemed highly lipolytic. Conversely, screening for proteolytic activity using azocasein as a substrate showed that $61.3 \%$ of the strains displayed proteolytic activity and 15 of them had values above $0.4 \mathrm{U} / \mathrm{min}^{*} \mathrm{~mL}$, which were considered highly proteolytic strains (Fig. 1b). However, the positive control (L. lactis) proteolytic activity was $0.87 \mathrm{U} / \mathrm{min}^{*} \mathrm{~mL}$, which was about two times higher than the isolated strains in this study.

Based on this screening, seven strains displayed both high lipolytic and proteolytic activity and were further subjected to gDNA extraction and identification by 16S rRNA gene sequencing. These strains corresponded to the following species isolated from commercial dairy products: one strain of Lactobacillus casei (L. casei OSU-PECh-C) isolated from whey protein isolate produced by Hilmar Ingredients (Hilmar CA, USA); two strains of Lactobacillus paracasei (L. paracasei OSU-PECh-BA) isolated from milk protein concentrate produced by Idaho Milk Products (Salt Lake City, UT, USA) and L. paracasei OSU-PECh-3B from buttermilk produced by Dairy America (Fresno, CA, USA); two strains of Lactobacillus plantarum (L. plantarum OSUPECh-A and L. plantarum OSU-PECh-BB) isolated from natural yogurt and pasteurized half and half, produced by Superior Dairy (Canton OH, USA); and two strains of Pediococcus acidilactici (P. acidilactici OSU-PECh-L) isolated from mozzarella cheese produced by Belgioioso (Green Bay, WI, USA) and (P. acidilactici OSU-PECh-3A) gouda cheese produced by Sargento (Plymounth, WI, USA).

\section{Localization of enzymatic activities in cell fractions}

After obtaining different cell fractions (supernatant, whole cells, intracellular, and cell-debris) by centrifugation and sonication from fresh cultures, respectively, the lipolytic, proteolytic, and antibacterial activities were evaluated. Figure $2 \mathrm{a}$ depicts lipolytic activity using $p$-NPA as the substrate. All seven strains exhibited the greatest hydrolysis of $p$-NPA in the cell supernatant relative to the rest of the fractions. OSUPECh-L had the greatest lipolytic activity in both the supernatant and whole cell fractions compared with the other six strains and fractions. The OSU-PECh-3A and OSU-PECh-BB strains had the greatest hydrolysis values in the intracellular fraction relative to the other fractions of those strains. The celldebris fraction from OSU-PECh-3B strain showed lipolytic activity (Fig. 2a).

Similar results were obtained for the proteolysis screening. The seven strains exhibited proteolytic activity in the supernatant fractions (Fig. 2b). The intracellular fraction of OSUPECh-L also showed high hydrolysis of azocasein. Conversely, the cell-debris fraction of all examined strains had low proteolytic activity. The OSU-PECh-A, OSUPECh-3B, OSU-PECh-BA, and OSU-PECh-BB strains had the greatest proteolysis in the whole cell fraction (Fig. 2b).

Antibacterial activity is shown in Fig. 3. Only two strains (OSU-PECh-L an OSU-PECh-3B) displayed hydrolysis in the supernatant fraction in the $\mathrm{N}$-acetylglucosaminidase assay (Fig. 3a). The maximum values of $\mathrm{N}$-acetylglucosaminidase activity was found in the intracellular fractions for four of the strains (OSU-PECh-C, OSU-PECh-3A, OSU-PECh-3B, and OSU-PECh-BA). The cell-debris fraction from OSU-PEChBA had the highest activity against the substrate. The whole cell fractions from all strains also showed activity but was considerably lower compared with that obtained in the intracellular fraction. For the N-acetylmuramoyl-L-alanine amidase assay (Fig. 3b), the supernatant fraction showed values in five of the seven strains evaluated. Moreover, the whole cell
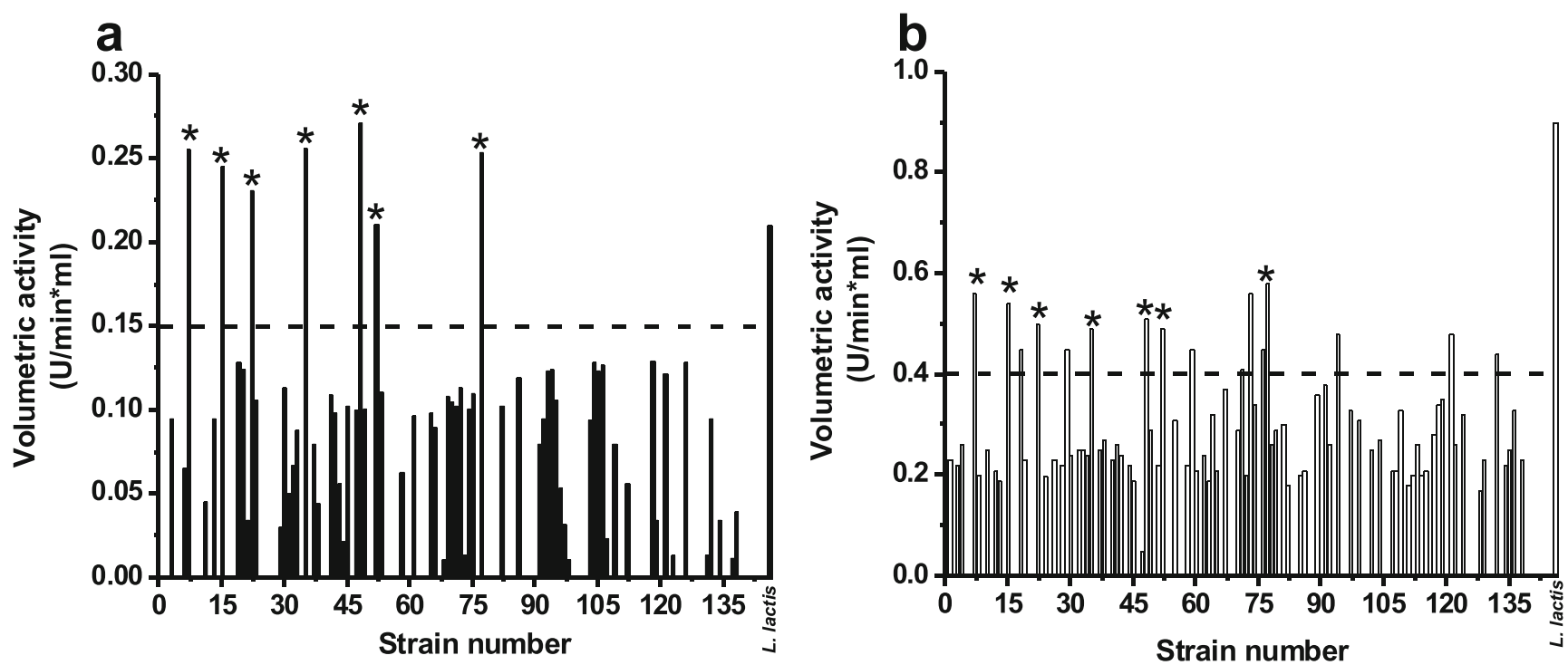

Fig. 1 Screening of a lipolytic and $\mathbf{b}$ proteolytic activities of 137 strains isolated from different dairy products. *corresponds to the selected strains. represents the cutoff for selection. L. lactis was used as a positive control 


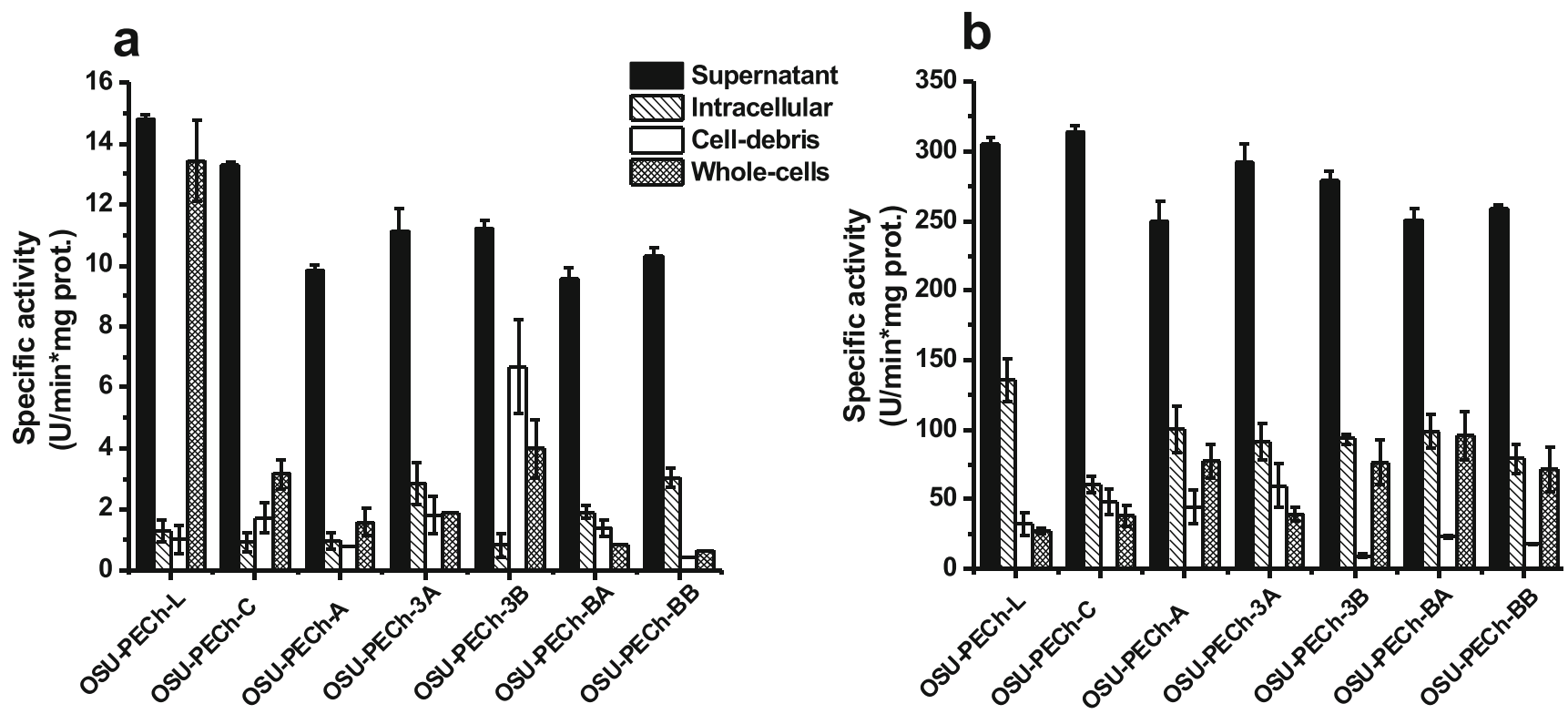

Fig. 2 Cell localization of enzymatic activities. a Lipolytic activity using $p$-NPA as substrate; b proteolytic activity using azocasein as substrate. Error bars represent standard deviation of three independent experiments

fraction also showed activity in six of the seven strains, with OSU-PECh-C and OSU-PECh-BA showing the highest activities. The intracellular and cell-debris fractions had the lowest activity in all strains. Figure $3 \mathrm{c}$ depicts $\mathrm{N}$-acetylmuramidase activity that hydrolyzes the cell wall of M. lysodeikticus. NAcetylmuramidase activity was observed in all fractions and strains; however, the cell-debris fraction from OSU-PECh-3A had the highest activity value. Also, intracellular fraction from OSU-PECh-3A and OSU-PECh-BB showed high hydrolysis of M. lysodeikticus. Overall, the whole cell fraction from all strains revealed the lowest antibacterial activity against the cell wall of M. lysodeikticus. In terms of endopeptidase activity (Fig. 3d), only two strains (OSU-PECh-BA and OSUPECh-BB) exhibited high hydrolysis of the substrate in the four fractions. The whole cell fraction exhibited endopeptidase activity in all 7seven strains, and OSU-PECh-L had the lowest activity, and the highest was OSU-PECh-C, among the bacteria tested.

In order to complement the aforementioned antibacterial activities, agar diffusion assays against pathogenic strains commonly found in dairy products were performed.

Table 1 shows the inhibition zone in $\mathrm{mm} / \mathrm{mg}$ protein of each fraction of the seven LAB strains. The supernatant and whole cell fractions of the seven strains inhibited growth of $E$. coli, with the exception of the supernatant from the strain OSU-PECh-A and OSU-PECh-BA and the whole cells fraction from OSU-PECh-3B. None of the intracellular and cell-debris fractions showed inhibition of $E$. coli. The target strain L. innocua was inhibited by several strains and fractions. In general, all whole cell fractions had the ability to inhibit this microorganism. The supernatant from OSU-PECh-L showed high inhibition of L. innocua, and the supernatants of OSUPECh-C and OSU-PECh-3B did not display antibacterial activity for $L$. innocua. Only three strains exhibited inhibition by the cell-debris fraction (OSU-PECh-A, OSUPECh-3A and OSU-PECh-BB). On the other hand, $S$. aureus and $S$. epidermidis had similar patterns of inhibition between the strains, and these were inhibited by all fractions of OSU-PECh-BA and OSU-PECh-BB. The four fractions from OSU-PECh-C exhibited activity against S. aureus.

\section{Identification and isolation of enzymes in zymograms}

Zymography was used to visualize the proteins responsible for lipolytic, proteolytic, and antibacterial activities in each fraction from the seven LAB strains. For lipolytic activity, native $10 \%$ PAGE was used to detected two proteins with experimental molecular weights of 86 and $67 \mathrm{kDa}$ from the intracellular fractions of OSU-PECh-3A and OSU-PECh-C, respectively (Fig. 4a, lane 1 and 2). Lipolytic activity of these proteins was not observed under denaturing and reducing conditions (with the addition of SDS, DTT, and Bmercaptoethanol, data not shown). To examine proteolytic enzymes, SDS-PAGE was used with casein as a substrate. The resulting gel led to the identification of seven different proteases (Fig. 4b). Species L. casei expressed three different proteases in the zymogram. One of these three proteins was located in the cell-debris fraction $(75 \mathrm{kDa}$, Fig. $4 \mathrm{~b}$ lane 2). The second protein, with a molecular weight of $53 \mathrm{kDa}$, was found in the intracellular fraction and the third protein $(40 \mathrm{kDa}$ ) in the supernatant fraction (Fig. 4b, lanes 5 and 7 , respectively). Three proteases were also observed in the 


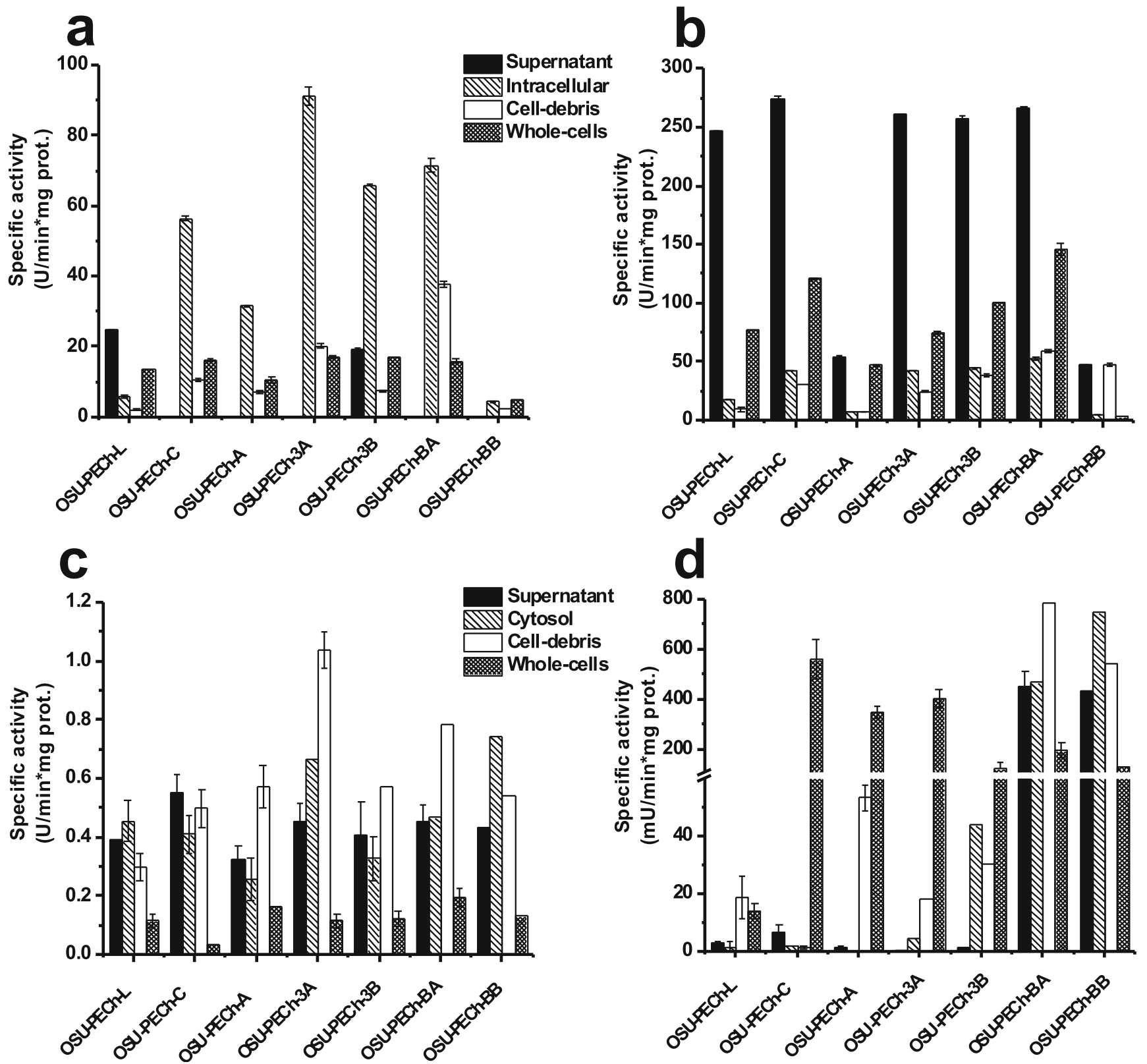

Fig. 3 Cell localization of antibacterial activities. a N-acetylglucosaminidase; b N-acetylmuramoyl-L-alanine amidase; c N-acetylmuramidase; and d endopeptidase activity. Error bars represent standard deviation of three independent experiments

intracellular fraction of L. paracasei, with molecular weights of 100, 65, and $47 \mathrm{kDa}$ (Fig. 4b, lanes 1, 4, and 6, respectively). Lastly, one $75 \mathrm{kDa}$ protease was found in the cell-debris fraction of $P$. acidilactici (Fig. 4b, lane 3). With regard to antibacterial activity, three proteins from the supernatant fraction with activity against M. lysodeikticus were detected. Two proteins were from OSU-PECh-3A strain with $45-\mathrm{kDa}$ of molecular weight, and the second was observed in the bottom part of the SDS-PAGE with a $5 \mathrm{kDa}$ molecular weight (Fig. 4c, lanes 1 and 2, respectively). The third antibacterial protein was observed in the OSU-PECh-3B strain with a $20 \mathrm{kDa}$ of molecular weight.

\section{Amino acid sequence analysis}

Amino acid sequence analysis identified 12 proteins with over $10 \%$ sequence identity to sequences reported in UniProtKB database. Table 2 shows the identity and putative functions of the different proteins identified by LC-MS/MS.

Lipolytic proteins Amino acid sequence analysis identified two proteins with esterase/lipase activity. The first was isolated from the intracellular fraction of OSU-PECh-3A with an observed molecular weight around $86 \mathrm{kDa}$ in a native zymogram (Fig. 4-A, lane 1). Trypsin digestion of this protein generated 3 peptides that matched a $45.5 \mathrm{kDa}$ putative 
Table 1 Agar diffusion against pathogenic strains commonly found in dairy products (mm inhibition/mg protein)

\begin{tabular}{|c|c|c|c|c|c|}
\hline Strain & Strain target & Supernatant & Intracellular & $\begin{array}{l}\text { Cell- } \\
\text { debris }\end{array}$ & Whole cells \\
\hline \multirow[t]{4}{*}{ P. acidilactici OSU-PECh-L } & E. coli & $58 \pm 6$ & 0 & 0 & $58 \pm 5$ \\
\hline & L. innосиа & $94 \pm 3$ & $49 \pm 3$ & 0 & $56 \pm 4$ \\
\hline & S. aureus & 0 & 0 & 0 & $60 \pm 3$ \\
\hline & S. epidermidis & 0 & 0 & 0 & $48 \pm 4$ \\
\hline \multirow[t]{4}{*}{ L. casei OSU-PECh-C } & E. coli & $74 \pm 3$ & 0 & 0 & $62 \pm 4$ \\
\hline & L. innocua & 0 & 0 & 0 & $92 \pm 6$ \\
\hline & S. aureus & $69 \pm 6$ & $45 \pm 8$ & $56 \pm 4$ & $41 \pm 4$ \\
\hline & S. epidermidis & 0 & 0 & 0 & $64 \pm 7$ \\
\hline \multirow[t]{4}{*}{ L. plantarum OSU-PECh-A } & E. coli & 0 & 0 & 0 & $30 \pm 4$ \\
\hline & L. inпосиа & $32 \pm 7$ & 0 & $30 \pm 6$ & $47 \pm 4$ \\
\hline & S. aureus & 0 & 0 & $34 \pm 6$ & $48 \pm 4$ \\
\hline & S. epidermidis & $44 \pm 4$ & 0 & 0 & $33 \pm 3$ \\
\hline \multirow[t]{4}{*}{ P. acidilactici OSU-PECh-3A } & E. coli & $84 \pm 4$ & 0 & 0 & $66 \pm 2$ \\
\hline & L. innосиа & $69 \pm 7$ & $43 \pm 8$ & $48 \pm 7$ & $106 \pm 5$ \\
\hline & S. aureus & 0 & 0 & 0 & $59 \pm 7$ \\
\hline & S. epidermidis & 0 & 0 & 0 & $77 \pm 3$ \\
\hline \multirow[t]{4}{*}{ L. paracasei OSU-PECh-3B } & E. coli & $68 \pm 4$ & 0 & 0 & 0 \\
\hline & L. inпосиа & 0 & 0 & 0 & $60 \pm 7$ \\
\hline & S. aureus & 0 & $55 \pm 4$ & $56 \pm 7$ & $65 \pm 4$ \\
\hline & S. epidermidis & 0 & $53 \pm 7$ & $30 \pm 6$ & $93 . \pm 2$ \\
\hline \multirow[t]{4}{*}{ L. paracasei OSU-PECh-BA } & E. coli & 0 & 0 & 0 & $58 \pm 4$ \\
\hline & L. innocua & $29 \pm 4$ & $56 \pm 2$ & 0 & $50 \pm 4$ \\
\hline & S. aureus & $69 \pm 4$ & $77 \pm 6$ & $108 \pm 6$ & $106 \pm 9$ \\
\hline & S. epidermidis & $100 \pm 4$ & $30 \pm 6$ & $56 \pm 2$ & $107 \pm 6$ \\
\hline \multirow[t]{4}{*}{ L. plantarum OSU-PECh-BB } & E. coli & $67 \pm 2$ & 0 & 0 & $64 \pm 3$ \\
\hline & L. innocua & $54 \pm 5$ & 0 & $86 \pm 3$ & $37 \pm 3$ \\
\hline & S. aureus & $57 \pm 4$ & $78 \pm 3$ & $86 \pm 3$ & $99 \pm 3$ \\
\hline & S. epidermidis & $86 \pm 3$ & $45 \pm 8$ & $68 \pm 4$ & $56 \pm 2$ \\
\hline
\end{tabular}

metallophosphoesterase from the $P$. acidilactici SRCM101189 genome. The difference in molecular weight suggests that the active oligomeric form is a dimer. This enzyme is part of a metal-dependent superfamily containing a conserved domain in the active site with histidine, aspartate, and asparagine residues. The second lipolytic protein, isolated from OSU-PECh-C, was a $67 \mathrm{kDa}$ protein as observed in the native zymogram (Fig. 4-A, lane 2). It was identified as a $35 \mathrm{kDa}$ esterase/lipase, suggesting that it is also found as a dimer in the active form. By definition, esterases and lipases hydrolyze the carboxylic ester bond of both short and longchain fatty acids.

Proteolytic enzymes Proteases were the most abundant polypeptides found in the bacterial cell fractions. The cellular location and molecular weights of 7 different proteins, each cleaving at specific amino acid residues, were identified. Three of these proteases were found in the L. casei genome, the first one produced 17 peptides after trypsin digestion and matched a $77.9 \mathrm{kDa}$ putative Clp protease (33\% coverage). This ATPdependent protease is a component of the Clp chaperoneprotease complex that is involved in protein degradation and disaggregation. Another protein, identified by 4 peptides after digestion, was an oligoendopeptidase with a molecular weight of $67 \mathrm{kDa}$. This protein belongs to the thermolysin-like family of proteinases and zinc-dependent metallopeptidases and is widely used as a nonspecific protease to degrade extracellular proteins and peptides for bacterial nutrition. The last $L$. case $i$ protease (identified by 4 peptides) was a serine protease with a putative molecular weight of $44.9 \mathrm{kDa}$. This protease cleaves peptide bonds using a specific set of amino acid residues in the active site, one of which is always a serine residue. In L. paracasei genus, 3 proteins were identified in the intracellular fraction. The first protease (identified by 6 peptides) is part of the Peptidase M1 family from the L. paracasei 25,302 genome and has a putative molecular weight of $94.4 \mathrm{kDa}$. This 


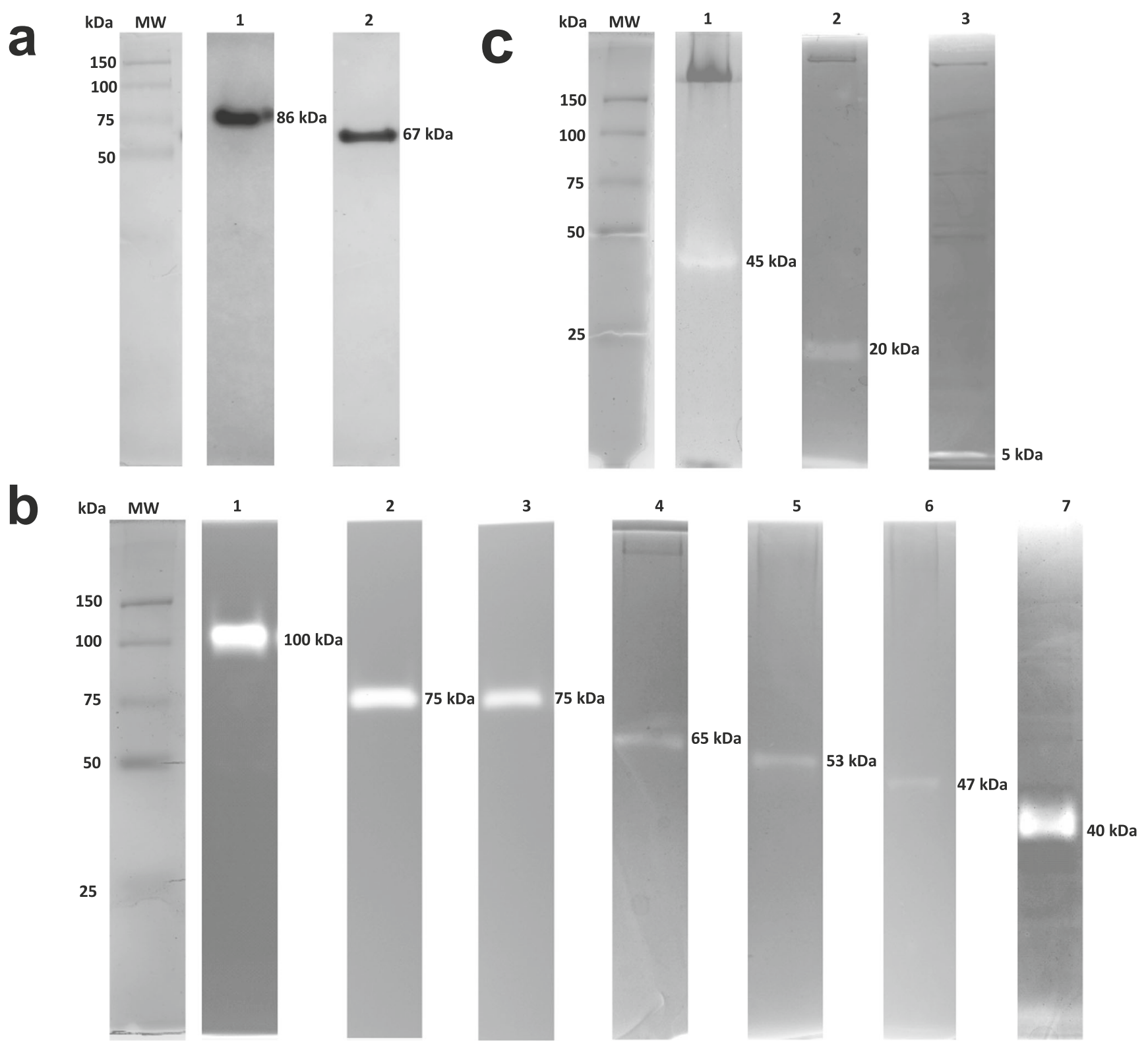

Fig. 4 Zymograms without SDS- and SDS-PAGE. a Lipolytic activity; lane 1, intracellular fraction from OSU-PECh-3A; lane 2, intracellular fraction from OSU-PECh-C. b Proteolytic activity; lane 1, intracellular fraction from OSU-PECh-3B; lane 2, cell-debris fraction from OSU$\mathrm{PECh}-\mathrm{C}$; lane 3, cell-debris fraction from OSU-PECh-3A; lane 4, intracellular fraction from OSU-PECh-BA; lane 5, intracellular fraction from

protein is from the aminopeptidases- $\mathrm{N}$ and glutamylaminopeptidase group, which release $\mathrm{N}$-terminal glutamate from peptides. Six peptides were produced after trypsin digestion of the second protease, which was identified as a $71.3 \mathrm{kDa}$ neutral endopeptidase from the $L$. paracasei genome. This protein is from the peptidase M13 family and is used to digest milk proteins. The third protein (identified by 6 peptides after digestion) was a $50.5 \mathrm{kDa}$ aminopeptidase $\mathrm{C}$ from $L$. paracasei DSM 20258. This exopeptidase is a cysteine peptidase that hydrolyses a peptide bond using the thiol-group active site of
OSU-PECh-C; lane 6, intracellular fraction from OSU-PECh-3B; lane 7, supernatant fraction from OSU-PECh-C. c Antibacterial activity; lane 1, supernatant fraction from OSU-PECh-3A; lane 2, supernatant fraction from OSU-PECh-3B; lane 3, supernatant fraction from OSU-PECh-3A. MW, molecular weight marker

a cysteine residue. Interestingly, the complete sequences of these three enzymes from $L$. paracasei strains did not show similarity between one another, settling that are different proteins (data not shown; MUSCLE, multiple sequence comparison by log-expectation).

Finally, a protease in the intracellular fraction of $P$. acidilactici OSU-PECh-3A was identified by 13 peptides from the trypsin digestion. This protein resembles an ATPdependent Clp protease with molecular weight of $77.9 \mathrm{kDa}$ ( $25 \%$ coverage). It had similar activity and a similar molecular 
Table 2 Identification of proteins by LC-MS/MS from different fractions of LAB

\begin{tabular}{|c|c|c|c|c|c|c|}
\hline Strain & Fraction & Protein function & No. peptides & $\%$ coverage & Access number & $\begin{array}{l}\text { Theoretical } \\
\text { MW (kDa) }\end{array}$ \\
\hline \multicolumn{7}{|l|}{ Lipases } \\
\hline P. acidilactici OSU-PECh-3A & Intracellular & Phosphoesterase & 3 & 10 & ARW28254.1 & 45.4 \\
\hline L. casei OSU-PECh-C & Intracellular & Esterase/lipase & 4 & 17 & CCK23986.1 & 35.0 \\
\hline \multicolumn{7}{|l|}{ Proteases } \\
\hline L. paracasei OSU-PECh-3B & Intracellular & Peptidase M1 & 6 & 10 & EEI69180.1 & 94.4 \\
\hline L. casei OSU-PECh-C & Cell-debris & Clp protease & 17 & 33 & CCK23115.1 & 77.9 \\
\hline P. acidilactici OSU-PECh-3A & Cell-debris & Clp protease & 13 & 25 & WP_070366152.1 & 77.9 \\
\hline L. paracasei OSU-PECh-BA & Intracellular & Neutral endopeptidase & 6 & 13 & WP_016379304.1 & 71.3 \\
\hline L. casei OSU-PECh-C & Intracellular & Oligoendopeptidase & 4 & 12 & CCK22105.1 & 67.4 \\
\hline L. paracasei OSU-PECh-3B & Intracellular & Aminopeptidase $\mathrm{C}$ & 6 & 28 & KRM98411.1 & 50.5 \\
\hline L. casei OSU-PECh-C & Supernatant & Serine protease & 4 & 12 & WP_071798966.1 & 44.9 \\
\hline \multicolumn{7}{|l|}{ Antibacterial proteins } \\
\hline P. acidilactici OSU-PECh-3A & Supernatant & $\mathrm{N}$-acetylmuramidase & 4 & 14 & WP_075139824 & 48.0 \\
\hline L. paracasei OSU-PECh-3B & Supernatant & Hydrolase-amidase & 3 & 18 & KRN07451 & 22.8 \\
\hline P. acidilactici OSU-PECh-3A & Supernatant & 50S ribosomal protein & 2 & 69 & WP_002832248.1 & 4.4 \\
\hline
\end{tabular}

weight to the L. casei OSU-PECh-C protease. However, multiple alignment between these proteases did not show similarity in amino acid sequence (data not shown).

Antibacterial proteins Lastly, three proteins with antibacterial activity were identified from the supernatant fractions. One of these belongs to the strain OSU-PECh-3A and was identified as a $48 \mathrm{kDa} \mathrm{N}$-acetylmuramidase using 4 peptides, which accounted for $14 \%$ coverage of the sequence. This protein is a peptidoglycan hydrolase that degrades bacterial cell walls through hydrolysis of $1,4-\beta$-linkages between $\mathrm{N}$ acetylmuramic acid and $\mathrm{N}$-acetylglucosamine residues. The second protein, found in OSU-PECh-3B, had a molecular weight of $20 \mathrm{kDa}$ and was digested into 3 peptides that represented $17.8 \%$ coverage. The protein was identified as a hydrolase-amidase with theoretical molecular weight of $22.8 \mathrm{kDa}$. This protein is structurally related to other amidohydrolases (i.e. $\mathrm{N}$-acetylmuramoyl-L-alanine amidase) that are involved in the degradation of the peptidoglycan and hydrolysis of the amide bond between $\mathrm{N}$-acetylmuramic acid and L-amino acids of the bacterial cell wall. The last protein found was the 50S ribosomal protein L36, which was identified by 2 peptides after digestion and matches $69 \%$ of the total sequence of this protein from the $P$. acidilactici 7 _ 4 genome. This protein has an experimental molecular weight of $5 \mathrm{kDa}$ and was found in the supernatant fraction of OSU-PECh-3A.

\section{Discussion}

LAB contribute to the flavor characteristics of fermented food products as a result of fat, protein, and carbohydrate breakdown. Lipolysis and proteolysis are significant in the fermentative processes of dairy products because the hydrolysis of triacylglycerols and proteins in milk produce favorable compounds. Previous studies have failed to consider both lipolytic and proteolytic activities concurrently. Some studies focusing on other fermented products, such as wine or meat, screened for either the lipolytic or proteolytic activity of bacteria (Kliche et al. 2017; Pérez-Martín et al. 2013). In this study, 137 strains isolated from dairy products were screened for both lipolytic and proteolytic activities. Seven strains displayed both high lipolytic and proteolytic activities. In the proteolysis experiments, the positive control (L. lactis) showed the greatest activity, however, some isolated strains also exhibited high activity values. Lipolysis was greatest in the isolated strains compared with the positive control. L. lactis was selected as the positive control because it is one of the most studied microorganisms in dairy products, it generates volatile compounds from the hydrolysis of milk fat, and it is capable of efficiently hydrolyzing milk proteins (Dhaisne et al. 2013). The seven strains with high lipolytic and proteolytic activities were selected and further examined with the intention of understanding the role of lactic acid bacteria during fermentation of dairy products and whether potentially healthful metabolites could be produced. These seven strains were genetically identified as: L. casei, two strains of L. paracasei, two strains of $L$. plantarum, and two strains of P. acidilactici.

Five of the seven strains isolated belong to the Lactobacillus genus, which has been generally characterized as lipase-producing. For example, lipases have been cloned, expressed, purified, and characterized in Lactobacillus plantarum, Lactococcus lactis, and Lactobacillus casei. 
These enzymes have since been applied to dairy products and have displayed a positive effect on the organoleptic proprieties of these foods (Esteban-Torres et al. 2014; Fernandez et al. 2000; Castillo et al. 1999). Another genus, Pediococcus, has been shown to be lipolytic; however, lipolytic activity of this genus is more frequently reported in the fermentation of grape must, wine, and meat products (Pérez-Martín et al. 2013; Vaquero et al. 2004; Ostdal et al. 1996). In this study, two $P$. acidilactici strains with high lipolytic activity were isolated from dairy products, which have the potential to influence the aromatic compounds and the sensory characteristics of the fermented foods. On the other hand, proteolytic activity has been reported several times for LAB, including Enterococcus, Lactobacillus, Lactococcus, and Pediococcus. In this work, 84 of 137 strains isolated had proteolytic activity, corresponding to $61.3 \%$ of the total isolates. This indicates that more than half of the LAB isolated from these dairy products have proteolytic activity and likely a direct effect on sensory properties, such as flavor formation and aroma in ripening foods (Simitsopoulou et al. 1997). The hydrolysis of proteins in milk (i.e., casein, $\beta$-lactoglobulin, and $\alpha$-lactalbumin) produces free amino acids and small peptides, which have been suggested to exhibit anti-inflammatory and antioxidant effects in humans (Kliche et al. 2017). Furthermore, these hydrolyzed peptides are beneficial to gut microbiota because they show antimicrobial activity and inhibit pathogenic microorganisms such as E. coli, L. monocytogenes, and $S$. aureus, thereby promoting the growth of LAB (Mohanty et al. 2016).

Out of all LAB, the proteolytic system of Lactococcus lactis is the most extensively studied in terms of regulation and hydrolysis of milk proteins as casein (Savijoki et al. 2006). Also, the Lactobacillus genus, specifically $L$. delbrueckii and $L$. helveticus, produce proteases that can hydrolyze $\alpha$ - and $\beta$-casein (Kliche et al. 2017). The Pediococcus genus displays high levels of proteolysis and is commonly found in meat and cheese products (Gandhi et al. 2016; Simitsopoulou et al. 1997). In this study, only two of the selected seven strains belong to the Pediococcus genus, while the other five strains belong to the Lactobacillus genus indicating a large range of species and characteristics of $\mathrm{LAB}$ found in dairy products.

Through investigating the subcellular localization and relative solubility of these enzymes, the processes involved in ripening and fermentation of dairy and meat products are becoming better understood. In this study, four subcellular fractions (the supernatant, intracellular, cell-debris, and whole cell fractions) were compared with understand the organization of the lipolytic, proteolytic, and antibacterial activity in LAB. The relationship between the location of these enzymes and their type of activity adds insight to their roles during dairy fermentation. This work provides evidence that lipolytic and proteolytic activities are apparent in the supernatant fraction, meaning these enzymes are released into extracellular space.
Together, this suggests that these enzymes are released into food matrices where they hydrolyze milk fat and proteins, thus, having a direct effect on flavor development and the biochemistry of dairy products. In correspondence with these findings, other authors have reported these activities in the supernatant fractions. For example, the extracellular fractions of L. acidophilus $\mathrm{O} 177$ and L. mesenteroides subsp. dextranicum $\mathrm{O} 257$ hydrolyzed tributyrin and buttermilk (Katz et al. 2002). In addition, the extracellular proteolytic system of LAB plays a key role in degrading casein into oligopeptides in milk medium, which can then utilize in their metabolic processes (Savijoki et al. 2006).

Some authors have also reported these activities in cell-free extracts (intracellular), implying the rupture of cells and release of intracellular enzymes into the matrix (Hong et al. 2018; Abeijon-Mukdsi et al. 2009; Sumby et al. 2009). The other fractions (cell-debris, supernatant, and whole cells) showed lower levels of lipolysis and proteolysis, suggesting less of these enzymes are present in these fractions and their respective strains that improve the organoleptic properties of dairy products (Pérez-Martín et al. 2013).

Antibacterial activity, such as $\mathrm{N}$-acetylglucosaminidase activity, is commonly found in the extracellular fraction which could pose multiple health benefits (Jankovic et al. 2010). In this study, two strains had extracellular Nacetylglucosaminidase activity. This enzyme degrades bacterial cell walls by catalyzing the hydrolysis of terminal, nonreducing $\mathrm{N}$-acetylglucosamine residues from oligosaccharides. It is believed that $\mathrm{N}$-acetylglucosaminidase activity could be beneficial to human health because it can process and metabolize free oligosaccharides in human milk. These products then play an important role in establishing and maintaining the infant gut microbiome while reducing nonbeneficial bacteria (Bidart et al. 2015). In addition, this study provided evidence of $\mathrm{N}$-acetylglucosaminidase activity intracellularly, where it is not commonly reported.

Antibacterial activity via N-acetylmuramoyl-L-alanine amidase was also examined and found mostly in the extracellular fractions. N-acetylmuramoyl-L-alanine amidase is significant to dairy products because it hydrolyzes the bond between the glycan polymer and peptide in peptidoglycan to destabilize it and release intracellular enzymes involved in cheese ripening and flavor characteristics (Jebava et al. 2011; Moscoso and Suárez 2000). Whole cells also showed activity, indicating that surface proteins on cell can hydrolyze amide bonds of peptidoglycan and release free amino groups, contributing to flavor and aroma of dairy products and as well the innocuity of the final product (Lortal and Chapot-Chartier 2005). There are many reports of $\mathrm{N}$-acetylmuramidase activity as an effective antibacterial agent, which cleaves the glycan bond of peptidoglycan in bacterial cell walls. This activity was found in supernatant, intracellular, and cell-debris fractions in this study and probably plays an important role in dairy processing, 
because it promotes flavor development by releasing intracellular compounds, such as lipases, proteases, and amino group. Additionally, it inhibits some microorganisms, decreasing the prevalence of undesirable bacteria in the product (Pang et al. 2014). N-acetylmuramidase activity was also reported in transgenic cattle milk to prevent mastitis in vitro (Yang et al. 2011). On the other hand, this study detected two strains with high activity against $S$. aureus cells in all fractions, indicating endopeptidase activity. This endopeptidase cleaves peptide bonds between two amino acids, especially in bacterial cell walls. Therefore, these strains can be used in milk or milk products to reduce the infection risk by $S$. aureus. Mitigation of this microorganism is significant because it causes both systematic and ocular infections in humans and acute mastitis in cows (Verbree et al. 2017). Additionally, after cell hydrolysis, intracellular compounds are released, which affect the organoleptic characteristics in dairy products. In order to complement the antibacterial activities, agar diffusion showed broad variation in inhibition of pathogenic strains commonly found throughout dairy processing. For example, pathogenic E. coli has a prevalence of approximately $0.9 \%$ in dairy products and causes foodborne diseases, like hemolytic uremic syndrome, diarrhea, and possibly death (Douëllou et al. 2017). This study found six strains with antibacterial activity against $E$. coli, which makes them promising starter culture strains in products with a high risk of $E$. coli contamination. On the other hand, the Listeria genus is frequently reported as pathogenic, and the prevalence in dairy products as yogurt, ice cream, and cheese are common (Rocourt and Buchrieser 2007). In this work, all bacteria and different fractions evaluated had a high activity against $L$. innocua, which indicates that the LAB studied can minimize the presence of this species in dairy products. In future studies, it would be interesting to evaluate the effectiveness against other pathogenic strains, such as $L$. monocytogenes and $L$. ivanovii that are of public health significance (Evert-Arriagada et al. 2018). S. aureus and $S$. epidermidis are the most contagious strains that produce bovine mastitis. For several years, milk producers, governments, and researchers have tried to reduce contamination by these microorganisms (Sunagar et al. 2013). In this study, three strains (and all the fractions of these strains) of LAB examined inhibited Staphylococcus genus, which suggests that the use of LAB in dairy products has a promising future for the reduction of these microorganisms.

A protein with lipolytic activity was detected by zymography in the intracellular fraction of $P$. acidilactici. This is the first lipase reported for the Pediococcus genus isolated from a dairy product, which under native PAGE had a molecular weight of $86 \mathrm{kDa}$. The peptides found by LC-MS/ MS indicate it is a putative metallophosphoesterase with a theoretical molecular weight of $45.5 \mathrm{kDa}$, suggesting that this protein is active as a homodimer. This protein has been previously reported in another microorganism, L. plantarum 2739.
Gobbetti et al. (1996) found this protein in the intracellular fraction with a molecular weight of $85 \mathrm{kDa}$, however, the first $15 \mathrm{~N}$-terminal amino acids had no similarity with the sequence reported for the intracellular esterase in P. acidilactici isolated in this study (data not shown; MUSCLE, multiple sequence comparison by log-expectation).

Several proteolytic enzymes identified by LC-MS/MS were observed in different cell fractions. The molecular weights detected by zymography were between 40 - and $100-\mathrm{kDa}$, indicating a large range of proteases that LAB produce. Proteolysis is a biochemical process important in the maturation or fermentation of dairy products. As mentioned above, the proteolytic system of LAB is well studied and has been classified as extracellular, membrane, and intracellular proteins. In general, casein hydrolysis begins with a cell-envelope proteinase that cleaves the protein into smaller peptides (oligopeptides). These oligopeptides are then transported into bacteria by other membrane transporters and peptidases that degrade the oligopeptides into amino acids (Savijoki et al. 2006).

In this study, proteases in the supernatant, membrane, and within the cell were detected and sequenced suggesting that other genera and species besides Lactococcus lactis show a similar proteolytic system to that described above. On the other hand, the seven identified proteins are reported as putative and have not been natively characterized.

Finally, two proteins with antibacterial activity and a third with suspected bacteriocin activity were identified. These are putative proteins and have not been reported so far. The first protein was identified from $P$. acidilactici with a $45 \mathrm{kDa}$ molecular weight by zymograms found in the supernatant fraction. The database reports that this protein has $\mathrm{N}$-acetylmuramidase activity. Although this genus is generally considered a bacteriocin-producer, recent reports show that Pediococcus is not exclusive to bacteriocin production and can present $\mathrm{N}$ acetylmuramidase, N-acetylmuramoyl-L-alanine amidase, or $\mathrm{N}$-acetylglucosaminidase activities against a broad spectrum of pathogenic bacteria found in food (Mora et al. 2003; García-Cano et al. 2015). The second protein is a hydrolaseamidase found in the supernatant fraction of $L$. paracase $i$ with a theoretical molecular weight of $22.8 \mathrm{kDa}$. This $20 \mathrm{KDa}$ protein showed lytic activity against M. lysodeikticus. The hydrolaseamidase protein family has been reported as highly active against $S$. aureus biofilms, significantly decreasing infections by this microorganism (Schmelcher et al. 2015). Several reports describe the antibacterial activities against foodborne pathogens found in bovine milk and dairy products. These enzymes have been used directly in bovine milk to decrease the presence of $S$. aureus and prevent the unwanted gas formation during cheese ripening (Schmelcher and Loessner 2016). The third antibacterial protein identified was a $5 \mathrm{kDa} 50 \mathrm{~S}$ ribosomal protein from $P$. acidilactici. At first, these low molecular weight proteins were believed to be a type of bacteriocin, called a pediocin, which also has a low molecular weight (Mora et al. 
2003). More recently, these low molecular weight proteins have been characterized in other species and identified as ribosomal proteins such as $30 \mathrm{~S}$ or $50 \mathrm{~S}$. For example, the low molecular weight antibacterial protein sakacin $\mathrm{P}(4.4 \mathrm{kDa})$ and a $30 \mathrm{~S}$ ribosomal protein $(6.8 \mathrm{kDa})$ both found in $L$. sakei have been reported with activity against $L$. monocytogenes (de Carvalho et al. 2010). Two 50S ribosomal proteins (11 and $6.5 \mathrm{kDa}$ ) with non-bacteriocin antibacterial activity in L. salivarius are also proteins with low molecular weight with antibacterial activity (Pidutti et al. 2018). These low molecular weight proteins can be classified as a new group of peptides with antibacterial activity. They can be used in foods in conjunction with other inhibitory proteins, such as those found in this project. By incorporating both these low molecular weight peptides and other antimicrobial proteins (each with different mechanisms of action) into dairy products, it is hypothesized that a synergistic antimicrobial effect against pathogenic bacteria will be produced and reduce the risk of some foodborne diseases.

Originally, it was suspected that LAB have the same or similar enzymatic activities. Despite these expectations, the bacteria studied in this work have unique activity profiles, showing promise for in vitro and in vivo applications. These bacteria have the potential add value to the safety and sensory attributes of dairy products, thus, presenting dual activities that favor the metabolism of lipids and proteins found in milk. The ability of different LAB to coexist in a single food implies the potential to use a selected consortium of bacteria with high values of enzymatic activities in the development of foods to promote consumer health.

Funding García-Cano is financially supported by the postdoctoral fellowship provided from CONACyT number 208631. This study was funded by the Parker Endowment at OSU (grant number 00100).

\section{Compliance with ethical standards}

Conflict of interest The authors declare that they have no conflict of interest.

Ethical approval This article does not contain any studies with human participants or animals performed by any of the authors.

Open Access This article is distributed under the terms of the Creative Commons Attribution 4.0 International License (http:// creativecommons.org/licenses/by/4.0/), which permits unrestricted use, distribution, and reproduction in any medium, provided you give appropriate credit to the original author(s) and the source, provide a link to the Creative Commons license, and indicate if changes were made.

\section{References}

Abeijon-Mukdsi MC, Medina RB, Katz MB, Pivotto R, Gatti P, Gonzalez SN (2009) Contribution of lactic acid bacteria esterases to the release of fatty acids in miniature ewe's milk cheese models. J Agric Food Chem 57(3):1036-1044. https://doi.org/10.1021/jf8026606
Álvarez-Sieiro P, Montalbán-López M, Mu D, Kuipers OP (2016) Bacteriocins of lactic acid bacteria: extending the family. Appl Microbiol Biotechnol 100:2939-2951. https://doi.org/10.1007/ s00253-016-7343-9

Atanasova J, Moncheva P, Ivanova I (2014) Proteolytic and antimicrobial activity of lactic acid bacteria grown in goat milk. Biotechnol Biotechnol Equip 28(6):1073-1078. https://doi.org/10.1080/ 13102818.2014.971487

Bendicho S, Martı G, Hernández T, Martın O (2002) Determination of proteolytic activity in different milk systems. Food Chem 79(2): 245-249. https://doi.org/10.1016/S0308-8146(02)00126-7

Bidart GN, Rodriguez-Diaz J, Yebra MJ (2015) The extracellular wallbound beta-N-acetylglucosaminidase from Lactobacillus casei is involved in the metabolism of the human milk oligosaccharide lacto-N-triose. Appl Environ Microbiol 82(2):570-577. https://doi. org/10.1128/AEM.02888-15

Burgain J, Scher J, Francius G, Borges F, Corgneau M, Revol-Junelles AM, Cailliez-Grimal C, Gaiani C (2014) Lactic acid bacteria in dairy food: surface characterization and interactions with food matrix components. Adv Colloid Interf Sci 213:21-35. https://doi.org/ 10.1016/j.cis.2014.09.005

Callewaert L, Walmagh M, Michiels CW, Lavigne R (2011) Food applications of bacterial cell wall hydrolases. Curr Opin Biotechnol 22(2):164-171. https://doi.org/10.1016/j.copbio.2010.10.012

Castillo I, Requena T, De Palencia PF, Fontecha J, Gobbetti M (1999) Isolation and characterization of an intracellular esterase from Lactobacillus casei subsp. casei IFPL731. J Appl Microbiol 86(4): 653-659. https://doi.org/10.1046/j.1365-2672.1999.00708.x

Collins YF, McSweeney PLH, Wilkinson MG (2003) Lipolysis and free fatty acid catabolism in cheese: a review of current knowledge. Int Dairy J 13:841-866. https://doi.org/10.1016/S0958-6946(03) 00109-2

De Carvalho KG, Bambirra FH, Kruger MF, Barbosa MS, Oliveira JS, Santos AM, Nicoli JR, Bemquerer MP, de Miranda A, Salvucci EJ (2010) Antimicrobial compounds produced by Lactobacillus sakei subsp. sakei $2 \mathrm{a}$, a bacteriocinogenic strain isolated from a brazilian meat product. J Ind Microbiol Biotechnol 37(4):381-390. https:// doi.org/10.1007/s10295-009-0684-y

Derrien M, van Hylckama Vlieg JE (2015) Fate, activity, and impact of ingested bacteria within the human gut microbiota. Trends Microbiol 23:354-366. https://doi.org/10.1016/j.tim.2015.03.002

Dhaisne A, Guellerin M, Laroute V, Laguerre S, Cocaign-Bousquet M, Le Bourgeois P, Loubiere P (2013) Genotypic and phenotypic analysis of dairy Lactococcus lactis biodiversity in milk: volatile organic compounds as discriminating markers. Appl Environ Microbiol 79(15):4643-4652. https://doi.org/10.1128/AEM.01018-13

Douëllou T, Delannoy S, Ganet S, Fach P, Loukiadis E, Montel M, Sergentet-Thevenot D (2017) Molecular characterization of O157: H7, O26: H11 and O103: H2 Shiga toxin-producing Escherichia coli isolated from dairy products. Int J Food Microbiol 253:59-65. https://doi.org/10.1016/j.ijfoodmicro.2017.04.010

El-Soda M, El-Wahab HA, Ezzat N, Desmazeaud MJ, Ismail A (1986) The esterolytic and lipolytic activities of the lactobacilli. II. Detection of esterase system of Lactobacillus helveticus, Lactobacillus bulgaricus, Lactobacillus lactis and Lactobacillus acidophilus. Lait 66:431-443. https://doi.org/10.1051/lait:1986428

Esteban-Torres M, Mancheño JM, de Las Rivas B, Muñoz R (2014) Production and characterization of a tributyrin esterase from Lactobacillus plantarum suitable for cheese lipolysis. J Dairy Sci 97(11):6737-6744. https://doi.org/10.3168/jds.2014-8234

Evert-Arriagada K, Trujillo A, Amador-Espejo G, Hernández-Herrero M (2018) High pressure processing effect on different Listeria spp. in a commercial starter-free fresh cheese. Food Microbiol 76:481-486. https://doi.org/10.1016/j.fm.2018.07.012

Fernandez L, Beerthuyzen MM, Brown J, Siezen RJ, Coolbear T, Holland R, Kuipers OP (2000) Cloning, characterization, controlled 
overexpression, and inactivation of the major tributyrin esterase gene of Lactococcus lactis. Appl Environ Microbiol 66(4):1360 1368. https://doi.org/10.1128/AEM.66.4.1360-1368.2000

Gandhi D, Chanalia P, Attri P, Dhanda S (2016) Dipeptidyl peptidase-II from probiotic Pediococcus acidilactici: purification and functional characterization. Int J Biol Macromol 93:919-932. https://doi.org/ 10.1016/j.ijbiomac.2016.09.023

García-Cano I, Serrano-Maldonado CE, Olvera-García M, DelgadoArciniega E, Peña-Montes C, Mendoza-Hernández G, Quirasco M (2014) Antibacterial activity produced by Enterococcus spp. isolated from an artisanal Mexican dairy product, cotija cheese. LWTFood Sci Technol 59(1):26-34. https://doi.org/10.1016/j.lwt.2014. 04.059

García-Cano I, Campos-Gómez M, Contreras-Cruz M, SerranoMaldonado CE, González-Canto A, Peña-Montes C, RodríguezSanoja R, Sánchez S, Farrés A (2015) Expression, purification, and characterization of a bifunctional $99-\mathrm{kDa}$ peptidoglycan hydrolase from Pediococcus acidilactici ATCC 8042. Appl Microbiol Biotechnol 99(20):8563-8573. https://doi.org/10.1007/s00253015-6593-2

Gobbetti M, Fox PF, Smacchi E, Stepaniak L, Damiani P (1996) Purification and characterization of a lipase from Lactobacillus plantarum 2739. J Food Biochem 20(1):227-246. https://doi.org/ 10.1111/j.1745-4514.1996.tb00553.x

Hong Q, Liu X, Hang F, Zhao J, Zhang H, Chen W (2018) Screening of adjunct cultures and their application in ester formation in camembert-type cheese. Food Microbiol 70:33-41. https://doi.org/ 10.1016/j.fm.2017.08.009

Jankovic I, Sybesma W, Phothirath P, Ananta E, Mercenier A (2010) Application of probiotics in food products-challenges and new approaches. Curr Opin Biotechnol 21:175-181. https://doi.org/10. 1016/j.copbio.2010.03.009

Jebava I, Plockova M, Lortal S, Valence F (2011) The nine peptidoglycan hydrolases genes in Lactobacillus helveticus are ubiquitous and early transcribed. Int J Food Microbiol 148(1):1-7. https://doi.org/10. 1016/j.ijfoodmicro.2011.04.015

Katz M, Medina R, Gonzalez S, Oliver G (2002) Esterolytic and lipolytic activities of lactic acid bacteria isolated from ewe's milk and cheese. J Food Prot 65(12):1997-2001. https://doi.org/10.4315/0362-028X65.12 .1997

Kliche T, Li B, Bockelmann W, Habermann D, Klempt M, de Vrese M, Wutkowski A, Clawin-Raedecker I, Heller K (2017) Screening for proteolytically active lactic acid bacteria and bioactivity of peptide hydrolysates obtained with selected strains. Appl Microbiol Biotechnol 101(20):7621-7633. https://doi.org/10.1007/s00253017-8369-3

Liu M, Bayjanov JR, Renckens B, Nauta A, Siezen RJ (2010) The proteolytic system of lactic acid bacteria revisited: a genomic comparison. BMC Genomics 11:36. https://doi.org/10.1186/1471-2164-11-36

Lortal S, Chapot-Chartier M (2005) Role, mechanisms and control of lactic acid bacteria lysis in cheese. Int Dairy J 15(6-9):857-871. https://doi.org/10.1016/j.idairyj.2004.08.024

McSweeney P, Sousa M (2000) Biochemical pathways for the production of flavour compounds in cheeses during ripening: a review. Lait 80: 293-324. https://doi.org/10.1051/lait:2000127

Mohanty DP, Mohapatra S, Misra S, Sahu PS (2016) Milk derived bioactive peptides and their impact on human health - A review. Saudi J Biol Sci 23(5):577-583. https://doi.org/10.1016/j.sjbs.2015.06.005

Mora D, Musacchio F, Fortina M, Senini L, Manachini P (2003) Autolytic activity and pediocin-induced lysis in Pediococcus acidilactici and Pediococcus pentosaceus strains. J Appl Microbiol 94(4):561-570. https://doi.org/10.1046/j.1365-2672.2003.01868.x

Morsky P (1983) Turbidimetric determination of lysozyme with Micrococcus lysodeikticus cells: reexamination of reaction conditions. Anal Biochem 128(1):77-85. https://doi.org/10.1016/00032697(83)90347-0
Moscoso M, Suárez JE (2000) Characterization of the DNA replication module of bacteriophage A2 and use of its origin of replication as a defense against infection during milk fermentation by Lactobacillus casei. Virology 273(1):101-111. https://doi.org/10.1006/viro.2000.0382

Østdal H, Baron CP, Blom H, Andersen HJ (1996) Production, isolation and partial characterization of a lipase-esterase from Pediococcus pentosaceus SV61. LWT-Food Sci Techol 29(5-6):542-546. https://doi.org/10.1006/fstl.1996.0082

Pang X, Cui W, Liu L, Zhang S, Lv J (2014) Gene knockout and overexpression analysis revealed the role of $\mathrm{N}$-acetylmuramidase in autolysis of Lactobacillus delbrueckii subsp. bulgaricus Ljj-6. PLoS One 9(8):e104829. https://doi.org/10.1371/journal.pone.0104829

Papagianni M (2012) Metabolic engineering of lactic acid bacteria for the production of industrially important compounds. Comput Struct Biotechnol J 3:e201210003. https://doi.org/10.5936/csbj. 201210003

Peña-Montes C, Mondragón-Tintor ME, Castro-Rodríguez JA, BustosJaimes I, Navarro-Ocaña A, Farrés A (2013) Immobilization and biochemical properties of the enantioselective recombinant NStcI esterase of Aspergillus nidulans. Enzyme Res 2013:928913. https://doi.org/10.1155/2013/928913

Pérez-Martín F, Seseña S, Izquierdo PM, Palop ML (2013) Esterase activity of lactic acid bacteria isolated from malolactic fermentation of red wines. Int J Food Microbiol 163(2-3):153-158. https://doi.org/ 10.1016/j.ijfoodmicro.2013.02.024

Pidutti P, Federici F, Brandi J, Manna L, Rizzi E, Marini U, Cecconi D (2018) Purification and characterization of ribosomal proteins L27 and L30 having antimicrobial activity produced by the Lactobacillus salivarius SGL 03. J Appl Microbiol 124(2):398-407. https://doi. org $/ 10.1111 /$ jam. 13646

Rocourt J, Buchrieser C (2007) The genus Listeria and Listeria monocytogenes: phylogenetic position, taxonomy, and identification. In: Ryser ET, Marth EH (eds) Listeria, listeriosis, and food safety, 3rd edn. CRC Press, Boca Raton, pp 1-20

Rodríguez-Rubio L, Gutiérrez D, Donovan DM, Martínez B, Rodríguez A, García P (2016) Phage lytic proteins: biotechnological applications beyond clinical antimicrobials. Crit Rev Biotechnol 36(3): 542-552. https://doi.org/10.3109/07388551.2014.993587

Savijoki K, Ingmer H, Varmanen P (2006) Proteolytic systems of lactic acid bacteria. Appl Microbiol Biotechnol 71(4):394-406. https:// doi.org/10.1007/s00253-006-0427-1

Schmelcher M, Loessner MJ (2016) Bacteriophage endolysins: applications for food safety. Curr Opin Biotechnol 37:76-87. https://doi. org/10.1016/j.copbio.2015.10.005

Schmelcher M, Shen Y, Nelson DC, Eugster MR, Eichenseher F, Hanke DC, Loessner MJ, Dong S, Pritchard DG, Lee JC (2015) Evolutionarily distinct bacteriophage endolysins featuring conserved peptidoglycan cleavage sites protect mice from MRSA infection. J Antimicrob Chemother 70(5):1453-1465. https://doi.org/10. 1093/jac/dku552

Simitsopoulou M, Vafopoulou A, Choli-Papadopoulou T, Alichanidis E (1997) Purification and partial characterization of a tripeptidase from Pediococcus pentosaceus K9.2. Appl Environ Microbiol 63(12): 4872-4876

Stuknyte M, Decimo M, Colzani M, Silvetti T, Brasca M, Cattaneo S, Aldini G, De Noni I (2016) Extracellular thermostable proteolytic activity of the milk spoilage bacterium Pseudomonas fluorescens PS19 on bovine caseins. J Dairy Sci 99(6):4188-4195. https://doi. org/10.3168/jds.2016-10894

Sumby KM, Matthews AH, Grbin PR, Jiranek V (2009) Cloning and characterization of an intracellular esterase from the wine-associated lactic acid bacterium Oenococcus oeni. Appl Environ Microbiol 75(21):6729-6735. https://doi.org/10.1128/AEM.01563-09

Sunagar R, Deore S, Deshpande P, Rizwan A, Sannejal A, Sundareshan S, Rawool D, Barbuddhe S, Jhala M, Bannalikar A (2013) Differentiation of Staphylococcus aureus and Staphylococcus 
epidermidis by PCR for the fibrinogen binding protein gene. J Dairy Sci 96(5):2857-2865. https://doi.org/10.3168/jds.2012-5862

Tanasupawat S, Phoottosavako M, Keeratipibul S (2015) Characterization and lipolytic activity of lactic acid bacteria isolated from Thai fermented meat. J App Pharm Sci 5(03):006-012. https:// doi.org/10.7324/JAPS.2015.50302

Vaquero I, Marcobal Á, Muñoz R (2004) Tannase activity by lactic acid bacteria isolated from grape must and wine. Int J Food Microbiol 96(2):199-204. https://doi.org/10.1016/j.ijfoodmicro.2004.04.004

Verbree CT, Datwyler SM, Meile S, Eichenseher F, Donovan DM, Loessner MJ, Schmelcher M (2017) Identification of peptidoglycan hydrolase constructs with synergistic staphylolytic activity in cow's milk. Appl Environ Microbiol 84(1):e02134-e02117. https://doi. org/10.1128/aem.02134-17
Yang B, Wang J, Tang B, Liu Y, Guo C, Yang P, Yu T, Li R, Zhao J, Zhang L (2011) Characterization of bioactive recombinant human lysozyme expressed in milk of cloned transgenic cattle. PLoS One 6(3):e17593. https://doi.org/10.1371/journal.pone.0017593

Zhou R, Chen S, Recsei P (1988) A dye release assay for determination of lysostaphin activity. Anal Biochem 171(1):141-144. https://doi.org/ 10.1016/0003-2697(88)90134-0

Publisher's note Springer Nature remains neutral with regard to jurisdictional claims in published maps and institutional affiliations. 